\title{
Pengaruh Jasa Pelayanan Terhadap Kinerja Dokter Spesialis Melalui Motivasi Dan Disiplin Kerja Di Rawat Jalan RSUD Banten
}

\author{
Tri Agus Yuarsa, Alih Germas Kodyat, Ahdun Trigono \\ UniversitasRespati Indonesia \\ Email : agusyuarsa@yahoo.com
}

\begin{abstract}
Abstrak
Pelayanan Rumah Sakit Umum Daerah (RSUD) Banten selaku rumah sakit rujukan di wilayah Provinsi Banten diharapkan berjalan secara optimal karena telah disiapkan tenaga dokter spesialis. Jasa Pelayanan yang didapatkan oleh dokter Spesialis berhubungan dengan Kinerja Dokter tersebut, dipengaruhi oleh factor motivasi dan disiplin kerja .Penelitian ini bertujuan untuk menguji dan menganalisa dengan Jalur path. Merupakan penelitian korelasional. Menggunakan Kuesioner melalui metode survey. Populasi penelitian ini adalah Dokter Spesialisdi RSUD Banten baik sebagai ASN (Aparatur Sipil Negara) atau Non ASN (tenaga Kontrak) yang berjumlah 32 dokter Spesialis. Hasil Penelitian pada Variabel Jasa Pelayanan yang berpengaruh pada responden adalah kesesuaian Gaji dengan Pekerjaannya sebagai dokter spesialis dengan presentasi $84.4 \%$. Pada variabel motivasi kerja adalah adanya Pekerjaan baru sebagai tantangan yang menyenangkan ( $84,4 \%)$, pada variabel disiplin Kerja adalah Hadir Tepat waktu saat bekerja dengan presentase $87,5 \%$. Variabel Kinerja berupa tidak membolos dalam bekerja sebesar $87,5 \%$, melayani pasien dan mendengarkan keluhan pasein sebesar 65,6\% dan Rapat dengan manajemen $81.2 \%$, melihat hasil ini maka kinerja dokter speialis sudah sesuai dengan SK Direktur RSUD Banten. Dimana Absensi 40 \%, Melayani Pasien 40 \% serta Rapat dengan Manajemen $20 \%$, Temuan dalam penelitian ini juga melihat koefisien jalur path, secara langsung motivasi dan disiplin berpengaruh terhadap Jasa Pelayanan dan Kinerja,sedangkan secara tidak langsung , melalui Jalur Disiplin kerja. Kesimpulan dan saran dalam hal pemberian Jasa Pelayanan maka diharapkan Pihak Manajemen atau Rumah sakit tetap konsisten dalam hal Jasa Ini. Manajemen mengajak dokter runtuk ikut berpartisipasi dalam pengambilan keputusan strategi dalam hal Pelayanan terhadap pasien, Kinerja dokter spesialis sudah sesuai dengan SK Direktur RSUD Banten .dimana Absensi 40 \%, Melayani Pasien $40 \%$ serta Rapat dengan Manajemen 20\%.
\end{abstract}

\section{Kata Kunci : Jasa pelayanan, Kinerja,Motivasi, DisiplinKerja, Jalur Path.}




\begin{abstract}
Banten Regional General Hospital (RSUD) as a referral hospital in Banten Province is expected to run optimally because specialist doctors have been prepared. Services obtained by specialist doctors are related to the doctor's performance, influenced by motivation and work discipline factors.

This study aims to test and analyze with the path line. It is a correlational study. Using a questionnaire through a survey method. The population of this research is specialist doctors in Banten Hospital either as ASN (State Civil Apparatus) or Non ASN (contract workers). Specialist.

The results of research on service variables that affect the respondent are the suitability of salary and work as a specialist with a presentation of $84.4 \%$. In the work motivation variable is the existence of a new job as a fun challenge (84.4\%), the Work discipline variable is Present on time at work with a percentage of $87.5 \%$. The performance variable is not truancy at work of $87.5 \%$, serving patients and listened to patients' complaints of $65.6 \%$ and meetings with management $81.2 \%$, seeing these results, the performance of the specialist doctors was in accordance with the Decree of the Director of Banten Hospital. Where attendance was 40\%, Serving Patients $40 \%$ and Meetings with Management 20\%, This research also looks at the path path coefficient, directly the motivation and discipline have an effect on Service Services and Performance, while indirectly, through the work discipline path.

Conclusions and suggestions in terms of providing services, it is hoped that the management or hospital will remain consistent in terms of these services. Management invites doctors to participate in strategic decision making in terms of service to patients, the performance of specialist doctors is in accordance with the SK Director of Banten Hospital. Attendance 40\%, Serving Patients 40\% and Meetings with Management 20\%.
\end{abstract}

Keywords: Services, Performance, Motivation, Work Discipline, Path line.

\section{PENDAHULUAN}

Mutu pelayanan merupakan hasil dari suatu sistem organisasi pelayanan kesehatan yang dipengaruhi oleh komponen struktur dan proses. Pelayanan Rumah Sakit Umum Daerah Banten selaku rumah sakit rujukan di wilayah Provinsi Banten diharapkan berjalan secara optimal karena telah disiapkan tenaga dokter spesialis sebanyak 40 orang. Status klasifikasi RSUD Banten sebagai Rumah Sakit Tipe B, Rumah Sakit Umum Kelas B adalah rumah sakit umum yang mempunyai fasilitas dan kemampuan pelayanan medik paling sedikit mempunyai 4 dokter spesialis dasar, 4 Dokter spesialis penunjang medik, 8 Dokter spesialislainnya dan 2 Dokter subspesialis dasar. Untukmenjadi RS pendidikan bila telah memenuhi persyaratan dan standar.

http://ejournal.urindo.ac.id/index.php/MARSI
Pelayanan Medik Spesialis Dasar adalah pelayanan medik dokter spesialis Penyakit Dalam, Dokter Kebidanan dan Kandungan, Dokter Spesialis Bedah dan dokter Spesialis Kesehatan

Anak.

Untuk Pelayanan Spesialis Penunjang terdiri dari Dokter Spesialis Radiologi, Spesialis Patologi Klinik, Spesialis Patologi Anatomi, Dokter Spesilis Anaestesi dan Reanimasi, Dokter Spesialis Rehabilitasi Medik. Pelayanan Medik Spesialis lain adalah pelayanan medik Dokter spesialis Telinga Hidung dan Tenggorokan, Dokter Spesialis Mata, Dokter Spesialis Kulit dan Kelamin, Dokter Spesialis Psikiatri, Dokter Spesialis Syaraf, Dokter Gigi dan Mulut, dokter Spesialis Jantung, Dokter Spesialis Paru, Dokter Spesialis Bedah Syaraf, Dokter Spesialis Ortopedi. Pelayanan Medik Sub Spesialis adalah 
satu atau lebih pelayanan yang berkembang dari setiap cabang medik spesialis. Seiring dengan operasional RSUD Banten, dokter Spesialis banyak di rekrut untuk dapat melakukan pelayanan kesehatan di RSUD Banten. Dengan berjalannya pelayanan kesehatan, Permasalahan muncul ketika. Puluhan dokter spesialis yang berpraktik di rumah sakit tersebut mempermasalahkan Jasa Pelayanan pasien yang tidak jelas didapatkan oleh para dokter Spesialis. Selain masalah pembagian Jasa pelayanan, Disiplin kerja yang terganggu serta sarana dan prasarana yang masih belum baik sebagai pemicu adanya keinginan sebagian dokter spesialis mengundurkan diri, hal ini sangat berpengaruh terhadap pelayanan yang diberikan oleh para dokter Spesialis. Sedangkan dari sudut manajemen mereka beranggapan motivasi, disiplinkerja dan Kinerja dokter spesialis sangat kurang sehingga mempengaruhi pelayanan yang diberikan oleh dokter spesialis kepada rumah sakit dan pasien yang datang berobat kerumah sakit Banten. Sehingga dari Permasalahan inilah yang melatarbelakangi penulis melakukan penelitian mengenai pengaruh Jasa Pelayanan terhadap Kinerja dokter Spesialis melalui Motivasi dan Disiplin Kerja di rawat jalan RSUD Banten.

Kinerja dapat didefinisikan sebagai suatu hasil kerja yang telah dilakukan oleh seseorang dalam suatu perusahaan atau organisasi sehingga dapat tercapainya tujuan dari suatu perusahaan atau organisasi tersebut serta dapat meminimalisir kerugian. Dengan kata lain, kinerja dapat kita artikan sebagai suatu kesediaan dari individu ataupun kelompok individu untuk dapat melakukan tugasnya serta menyelesaikannya sesuai dengan tanggungjawab dan dengan seperti yang diharapkan. Performance dikenalj juga dengan kinerja adalah hasi Ikerja yang dapat di capai oleh seseorang atau sekelompok orang dalam organisasi, sesuai dengan kewewenangan dan tanggung jawab dalam rangka atau upaya mencapai tujuan organisasi secara legal, tidak melanggar hukum dan sesuai dengan moral maupun etika. Kinerja dapat didefinisikan sebagai gambaran mengenai tingkat pencapaian pelaksanaan suatu kegiatan atau program suatu kebijakan dalam mewujudkan sasaran, tujuan, misi serta visi organisasi yang tertuang dalam rencana strategi suatu organisasi.

Kinerja dapat dilihat jika individu atau kelompok individu tersebut memiliki kriteria keberhasilan yang telah ditetapkan. Kriteria keberhasilan ini berupa tujuan atau target yang hendak dicapai. Kaitannya dengan konsep kinerja, terlihat bahwa ciri khas individu seperti kepribadian, usia dan jenis kelamin, taraf Pendidikan, suku bangsa, status social ekonomi, pengalaman terhadap keadaan yang lalu, akan dapat menentukan perilaku kerja dan produktivitas, baik perorangan maupun organisasi sehingga menimbulkan kepuasan bagi pelanggan atau pasien. Penilaian kinerja Pegawai dilakukan secara obyektif, tepat dan didokumentasikan secara baik. 
Dalam proses penilaian kinerja terlebih dahulu harus dilakukan pembuatan instrument penilaian kinerja yang berisi kriteria-kriteria penilaian kinerja yang spesifik sehingga kinerja dapat diukur dengan tepat. Penilaian kinerja dokter bertujuan untuk memahami kekurangan dari kinerja yang telah dilakukan sehingga dapat membuka ruang bagi improvement atau perbaikan terhadap mutu dan efisiensi rumahsakit, untuk keperluan pemberian insentif dan program rewards serta value-based purchasing strategies.Council of Medical Specialty Societies memberikan pernyataan bahwa penilaian kinerja dokter bermanfaat untuk memberikan informasi dan perubahan pembayaran insentif yang pada akhirnya akan memperbaiki pelayanan kesehatan yang diberikan oleh dokter, dimana keterlibatan seorang dokter bisa menjadi kunci utama keberhasilannya.

Rumah sakit diharapkan mampu untuk melakukan penilaian kinerja dokter dengan menggunakan instrument penilaian kinerja yang terstandarisasi, hal ini terutama dikaitkan dengan pola pembayaran dari payer yang memaksa rumah sakit memberlakukan sistem pay for performance dan peningkatan demand dari masyarakat akan pelayanan kesehatan yang bermutu tinggi.

Motivasi adalah memberikan dorongan kepada pegawai untuk melakukan kegiatan yang lebih baik. Dapat juga dikatakan bahwa motivasi adalah faktor yang mendorong seseorang untuk bertindak dengan cara tertentu. Adapun pengertian motivasi menurut T. Hani Handoko
(2011:252), motivasi adalah "keadaan dalam pribadi seseorang yang mendorong keinginan individu untuk melakukan kegiatan-kegiatan tertentu guna mencapai tujuan." Kemudian menurut Anwar Prabu Mangkunegara (2014:61) motivasi adalah "kondisi atau energi yang menggerakkan diri karyawan yang terarah atau tertuju untuk mencapai tujuan organisasi perusahaan". Menurut George R Terry dalam Serdamayanti (2014:233) mengemukakan bahwa motivasi adalah "keinginan yang terdapat pada seorang individu yang merangsangnya melakukan tindakan." Sedangkan menurut Serdamayanti (2014:233), motivasi adalah "kesediaan mengeluarkan tingkatan upaya tinggi kearah tujuan organisasi yang dikondisikan oleh kemampuan upaya itu untuk memenuhi kebutuhan individual." Kemudian Edy Sutrisno (2016:110) menyebutkan bahwa motivasi adalah "sesuatu yang menimbulkan dorongan kerja." Dari beberapa pengertian diatas dapat disimpulkan bahwa motivasi adalah suatu dorongan yang menggerakkan seseorang untuk ikut serta dalam mencapai tujuan yang telah ditetapkan perusahaan.

Disiplin Kerja merupakan suatu sikap, tingkah laku dan perbuatan yang sesuai dengan peraturan perusahaan baik yang tertulis maupun yang tidak tertulis. Peraturan yang dimaksud adalah absensi tepat waktu, lambat masuk kerja, serta cepat pulang bagi karyawan. Hal ini merupakan suatu sikap indisipliner karyawan yang perlu disikapi dengan baik oleh pihak manajemen. Keteladanan seorang 
pimpinan yang baik akan diikut baik oleh bawahan atau staff. Sebagai seorang pimpinan harus menyadari bahwa dirinya menjadi contoh dan diteladani oleh bawahannya, untuk itu pimpinan harus mempunyai kedisiplinan yang baik agar bawahan juga dapat melaksanakan disiplin yang baik.

Tindakan nyata yang paling efektif dalam mewujudkan disiplin kerja. Selain mengawasi disiplin kerja karyawan, waskat juga mencari system kerja yang efektif untuk mewujudkan tujuan organisasi dan karyawan. Pimpinan harus berani dan bertindak tegas untuk menghukum setiap karyawan yang indisipliner sesuai dengan sanksi. Dengan demikian, pada penelitian ini yang dimaksud dengan Disiplin Kerja adalah kedisiplinan yang merupakan keinginan dan kesadaran untuk mentaati peraturan organisasi dan norma sosial.

Oleh karena itu disiplin merupakan sarana penting untuk mencapai tujuan, maka pembinaan disiplin merupakan bagian dari manajemen yang sangat penting. Dengan berkembangnya ilmu pengetahuan, maka semakin dibutuhkannya suatu alat tukar yang berlaku umum dan untuk itulah diciptakan uang. Disamping itu, manusia juga memerlukan jasa yang mengurus hal- hal tertentu, sehinggajasamenjadibagianutamadala mpemasaran.

Kompensasi Menurut Supranto (2006, p227), jasa atau pelayanan merupakan suatu penampilan Kinerja, tidak berwujud dan cepat http://ejournal.urindo.ac.id/index.php/MARSI hilang, lebih dapat dirasakan daripada dimiliki, serta pelanggan lebih dapat berpartisipasi aktif dalam proses mengkonsumsi jasa tersebut. Dalam strategi pemasaran, definisi dari jasa harus diamati dengan baik, karena pengertiannya sangat berbeda dengan produk berupa barang. Kondisi dan cepat lambatnya pertumbuhan jasa akan sangat tergantung pada penilaian pelanggan terhadap kinerja (penampilan) yang ditawarkan oleh pihak produsen.

Besarnya kompensasi upah ditetapkan atas kesatuan unit yang dihasilkan pekerja. Dalam system hasil, besar kompensasi yang dibayar selalu didasarkan kepada kebanyaknya hasil yang dikerjakan bukan kepada lamanya waktu mengerjakannya. Sistem hasil ini tidak mempunyai standar fisik, seperti bagi karyawan administrasi. Sistem Borongan adalah suatu cara pengupahan yang penetapan besarnya jasa didasarkan atas volume pekerjaan dan lama mengerjakannya.

\section{KERANGKA KONSEP PENELITIAN}

Disiplin kerja adalah keinginan dan kesadaran untuk mentaati suatu peraturan organisasi dan norma sosial. Imbalan Jasa atau Jasa Pelayanan secara tidak langsung merupakan imbalanjasa yang diterima pekerja tidak secara rutin, imbalan ini mencakup fasilitas transportasi, biaya pemeliharaan kesehatan, upah selama cuti atau meninggalkan pekerjaan, bantuan untuk kecelakaan kerja, bantuan Pendidikan gratis, asuransi jamsostek dan iuran 
pensiunan. Batasan yang diperlukan dalam penelitian ini, Jasa Pelayanan adalah semua pengeluaran yang dikukan Rumah Sakit diperutukan dan diterima serta dinikmati oleh dokter. Proses penilaian kinerja dokter sebagai tenaga professional utama di rumah sakit harus dilakukan secara realistis, obyektif dan berbasis bukti serta spesifik sesuai spesialisasi dan atau prosedur spesifik.Penilaian kinerja dokter bertujuan untuk memahami kekurangan dari kinerja yang telah dilakukan sehingga dapat membuka ruang bagi improvement atau perbaikan terhadap mutu dan efisiensi rumah sakit, untuk keperluan pemberian insentif dan program rewards serta value-based purchasing strategies .

\section{METODE}

\section{Desain Penelitian}

Tempat penelitian ini adalah dirawat jalan atau poli Dokter Spesialis yang bekerja di RSUD Banten, baik Dokter Spesialis ASN atau Dokter Spesialis Non ASN. Populasi penelitian ini seluruh Dokter Spesialis yang bekerja di RSUD Banten baik sebagai ASN atau Non ASN yang berjumlah 32 Dokter Spesialis. Tehnik pengumpulan data yang digunakan dalam penelitianini adalah menggunakan angket/ kuesioner. Angket merupakan serangkaian daftar pertanyaan yang disusun secarasistematis, kemudian diisi oleh respondent, setelah diisi angket dikirim Kembali atau dikembalikan kepetugas atau peneliti.
Pertanyaan yang diajukan adalah pertanyaan tertutup, yaitu kuesioner yang disusun sedemikian rupa untuk merekam data tentang keadaan responden sendiri. Semua pertanyaan harus dijawab oleh responden telah tertera dalam kuesioner tersebut. Responden harus memilih salah satu jawaban yang menurut pendapatnya paling benar dan tidak diberi kesempatan untuk memberikan jawaban yang lain.

Kuesioner tersebut sudah dilakukan uji validitas dan reabilitas,sebelum di berikan kepada dokter spesialis sebagai responden, hasilnya semua data sudah valid.

Analisa data sebelum dilakukan uji bivariat hasil pengumpulan data dilakukan uji klasik untuk mengetahui normalitas dan homogenitas data, metode yang digunakan adalah Uji multi kolinieritas dilakukan dengan melihat toleransi value dan Value inflating factor. Apabila nilai signifikasi> 0,05 maka terjadi homogenetas dan ini yang seharusnya terjadi, namun jika sebaliknya nilai signifikasi $<0,05$ maka terjadi heterogenetas.

Analisis Bivariat, tujuan analisaini adalah untuk melihat beda proporsi dan hubungan antara masing-masing variabel dependent dan variable independent, sekaligus untuk melakukan identifikasi variabel yang bermakna atau tidak bermakna yaitu dengan uji Chi-square.Analisis uji statistik dengan Chi Square, memakai aplikasi SPSS . Denga melakuka analisa tabulasi yang bertujuan mengetahui hubungan 
independent yang meliputi motivasi, Disiplin kerja, dan Jasa Pelayanan Dokter spesialis di instalas rawat jalan di RSUD Baten dengan variabel kinerja sebagai dependent variabel terikat pada penelitian ini Multivariat bertujuan untuk melihat keeratan hubungan antara variabel dependent dengan variabel Independent secarabersama-sama.

Gambaran Umum RSUD Banten. Pembangunan RSU Banten yang dimulai pada tahun anggaran 2007 merupakan salah satu upaya yang dilakukan oleh Pemerintah Provinsi Banten dalam memberikan pelayanan kesehatan yang optimal terutama kesehatan pada masyarakat Banten. Karena dengan semakin berkembangnya Banten sebagai Provinsi, semakin kompleks juga masalah kesehatan yang dihadapi. Rumah Sakit Umum Banten diresmikan oleh Wakil Gubernur Banten pada tanggal 4 Oktober 2013, dan menjadi salah satu instansi Pemerintah Provinsi Banten yang bertanggung jawab dalam melayani Kesehatan rujukan atau lanjutan di Provinsi

Banten.

VISI dan MISI RSUD BANTEN, sesuai dengan cita-cita dan harapan khususnya masyarakat di lingkungan Provinsi Banten. Secara aktif program pemerintah di bidang Kesehatan sesuai RPJMD Provinsi Banten. Instalasi Unit Rawat Jalan RSUD Banten.
HASIL

Responden Berdasarkan Umur didapatkan ratarata berumur $35-44$ tahun sebesar $38 \%$ dari 32 responden. $31 \%$ berumur 25-34 Tahun dan Umur lebih dari 56 tahun sebesar 3\% atau hanya 1 orang Dokter. Berdasarkan Jenis Kelamin,rata-rata dokter spesialis yang ada di RSUD Banten adalah berjenis Kelamin Perempuan 59\%. Status Perkawinan pada responden didapatkan hasil rata-rata sudah menikah sebesar $97 \%$ hanya $3 \%$ yang belum menikah.

Responden berdasarkan Pendidikan Akademik $100 \%$ adalah Stara 2 setingkat Magister. Responden berdasarkan Status Kepegawaian terdiridari $50 \%$ ASN dan 50\% Non ASN dari 32 responden. Berdasarkan Lama kerja sebagai Dokter Spesialis di RSUD Banten, rata-rata 68\% sebanyak 22 responden sudah bekerja antara 0 -10 tahun, 32\% lama kerja 11-20 Tahun. Pemahaman responden mengenai jasa pelayanan didapatkan nilai mean ratarata 2,57 , median rata-rata 2,67 , dan modus rata-rata 2,67. Persentasi responden dalam hal jasa pelayanan menurut kesesuaian gaji dengan pekerjaan, pembayaran gaji tepat waktu, pemberian

tunjangan Kinerja, pemberianTunjangan THR, $p$ emberian tunjangan profesi dan pemberian asuransi BPJS diperoleh persentasi responden secara baik dengan Nilai 55,21\% Pemahaman responden terhadap motivasi dieroleh secara statistik, mendapat nilai mean rata-rata 3,09, median rata-rata 3,25 , dan modus rata-

rata 3,13 , 
Permahaman responden mengenai Motivasi secara umum adalah baik persentasi responden terhadap motivasi dalam hal pemenuhan kebutuhan, Kecukupan istirahat, sikap organisasi, sikap dalam bekerja, tanggung jawab, pengalaman

tugas, gaji, rasa nyaman, rasa aman hubungan dengan sesama dokter spesialis, pujian, tidak mengeluh dan tantangan dalam pekerjaan. Didapatkan Rerata 67 \% responden mengatakan baik, 29,3\% sangat baik, 3,3\% cukup baik dan 0,4\% respondemengatakan kurang baik.

Persepsi responden terhadap disiplin kerja dokter spesialis secara statistik, nilai mean ratarata 3,1 , median rata-rata 3,2 , dan modus ratarata 3,1 nilai ketiga data tersebut secara statistik nilainya hampir sama, persepsi responden terhadap disiplin kerja Dokter spesialis secara umum adalah baik.

Persentasi responden terhadap disiplin kerja Dokter spesialis menurut kehadiran tepat waktu, mengerjakan tugas yang menjadi tanggung jawab, mentaati jam kerja, meggunakan waktu secara tepat, melaksnakan tugas dengan baik, menggunakan jas putih, bekerja enam hari dalam satu minggu dan memelihara peralatan kedokteran yang digunakan rerata $70,7 \%$ disiplin kerja Dokter spesialis baik, 25,8\% sangat baik, 3,1\% cukup baik dan 0,4\% kurang baik

Persepsi responden terhdap kinerja Dokter spesialis didapatkan secara statistik, nilai mean rata-rata 3,00 , median rata-rata 3,23 dan modus rata-rata 3,00 , nilai ketiga data tersebut secara statistik nilainya hampir sama, hal ini menunjukkan tingkat persepsi responden terhadap Kinerja Dokter spesialis adalah baik. Persentasi responden terhadap kinerja Dokter spesialis berdasarkan tidak membolos dalam bekerja, Hadir tepat waktu, ramah melayani pasien, melakukan pemeriksaan dengan teliti dan cermat, mendengar kakeluhan pasien dengan baik, serta mengikuti rapat dengan manajeman dalam hal pelayanan rumah sakit didapatkan 70,9\% kinerja Dokter spesialis baik, $26 \%$ sangat baik dan 3,1\% cukup baik

\section{Uji Klasik}

Pada uji Normalitas dengan menggunakan Kolmogorov Smirnov diperoleh angka P 0,343 artinya $\mathrm{P}$ lebih besar dari 0,05 berarti data kita normal . Dan tidak terdapat perbedan data yang signifikan.

Pada Uji Homogenitas diperoleh nilai Significant 0,089 yang berarti lebih dari 0,05 $(>0,05)$ berarti data tersebut diatas adalah Homogen.

Uji Jalur ( PathAnalisis) $\rightarrow$ Untuk mengetahui Pengaruh langsung dan tidak langsung semua variabel X1 ( Jasa pelayanan), X2 ( Motivasi), X3 (Disiplin Kerja) dan Y (Kinerja Dokter)

\section{Pengaruhlangsung}

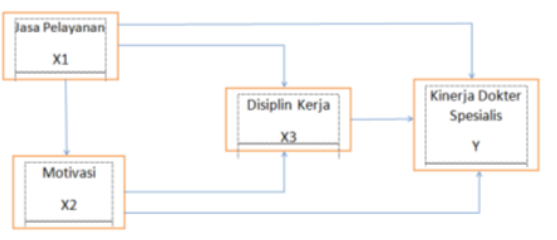

1. Jalur X1 (Jasa Pelayanan) dengan X2( Motivasi)

Dari hasil perhitungan koefisien Jalur ini $\mathrm{X}_{1}$ ke $\mathrm{X}_{2} \quad\left(\mathrm{Px}_{2} \mathrm{X}_{1}\right)$ didapatkan Koefisien jalur sebesar 53,5 \% $(0,535)$.Untuk uji hipoteses 
diperoleh nilai $\mathrm{t}=3,465>\mathrm{t}$ table $=$ 2,042, dan nilai $p$-value $=0,002$ $<0,05$, iniberarti H01 ditolak, dengan demikian variable Jasa Pelayanan (X1) berpengaruh langsung secara positif terhadap variabel Motivasi (X2).

\section{Jalur Motivasi (X2) terhadap Kinerja} (Y)

Dari hasil perhitungan koefisien Jalur ini $\mathrm{X} 2$ ke $\mathrm{Y} \quad\left(\mathrm{Px}_{2} \mathrm{Y}\right)$ didapatkan Koefisien jalur sebesar $40 \%(0,4)$ Untuk uji hipoteses diperoleh nilai nilai $0,023<0,05$, atau $t 2,390>t$ 2,042 dan nilai $p$-value = $0,023<0,05$, ini berarti H01 ditolak, dengan demikian variable motivasi (X2) berpengaruh langsung secara positif terhadap variabel Kinerja Dokter (Y).

\section{Jalur Jasa Pelayanan (X1)}

\section{terhadapDisiplin (X3)}

Dari hasil perhitungan koefisien Jalur ini $\mathrm{X} 1$ ke $\mathrm{X} 3 \quad\left(\mathrm{Px}_{1} \mathrm{X}_{3}\right)$ didapatkan Koefisien jalur sebesar 7\% $(0,07)$. Untuk uji hipoteses diperoleh nilai nilai $0,704>0,05$, atau $\mathrm{t} 0,384<\mathrm{t}$ 2,042, dan nilai $p$-value $=0,002$ $<0,05$, iniberarti HO ditolak, dengan demikian variable Jasa Pelayanan (X1) tidak berpengaruh langsung terhadap variabel disiplin kerja (X3).
4. Jalur Jasa Pelayanan (X1) terhadap Kinerja (Y)

Dari hasil perhitungan koefisien Jalur ini $\mathrm{X} 1$ terhadap $\mathrm{Y}\left(\mathrm{Px}_{2 \mathrm{Y}}\right)$ didapatkan Koefisien jalur sebesar 22,4\% $(0,224)$ Untuk uji hipoteses diperoleh nilai t $1,260<\mathrm{t} 2,042$, dan nilai $p$-value $=$ 0,217>0,05, ini berarti HO ditolak, dengan demikian variable Jasa Pelayanan (X1) tidak berpengaruh langsung terhadap variabel kinerja Dokter (Y).

\section{Jalur Motivasi (X2) terhadap Disiplin Kerja (X3)}

Dari hasil perhitungan koefisien Jalur ini $\mathrm{X} 2$ ke $\mathrm{X} 3\left(\mathrm{Px}_{2} \mathrm{X}_{3}\right)$ didapatkan Koefisien jalur sebesar 21,5\% (0,215). Untuk uji hipoteses diperoleh nilai t 1,206 < t 2,042, dan nilai p-value $=0,237$ $>0,05$, ini berarti HO ditolak, dengan demikian variable Motivasi (X2) tidak berpengaruh langsung terhadap variabel disiplin kerja (X3)

\section{Jalur Disiplin Kerja(X3) terhadap Kinerja ( $Y$ )}

Dari hasil perhitungan koefisien Jalur ini X3 ke $\mathrm{Y}\left(\mathrm{Px}_{3} \mathrm{y}\right)$ didapatkan Koefisien jalur sebesar 53,6\% (0,535). Untuk uji hipoteses diperoleh nilai $\mathrm{t}=$ $3,478>$ t table $=2,042$, dan nilai $p$ value $=0,002<0,05$, ini berarti $\mathrm{H} 1$ diterima, dengan demikian variable disiplin kerja (X3) berpengaruh 
langsung secara positif terhadap variabel kinerja Dokter (Y).

Rangkuman hasil perhitungan dan Pengujian koefisien jalur pengaruh langsung

Rangkuman hasil perhitungan dan pengujian koefisien jalur pengaruh langsung

\begin{tabular}{|c|c|c|c|c|c|}
\hline \multirow[t]{2}{*}{\begin{tabular}{|l|} 
Jalur \\
\end{tabular}} & \multirow{2}{*}{$\begin{array}{l}\text { Koefisien } \\
\text { jalur }\end{array}$} & \multirow[t]{2}{*}{ t hitung } & \multicolumn{2}{|l|}{$\mathrm{t}$ tabel } & \multirow[t]{2}{*}{ Keterangan } \\
\hline & & & $\begin{array}{l}\alpha \\
0.05\end{array}=$ & $\alpha=0.01$ & \\
\hline $\mathrm{Px}_{2} \mathrm{x}_{1}$ & 0,535 & 3,465 & 1.67 & 2.39 & Berpengaruh \\
\hline $\mathrm{Px}_{2} \mathrm{y}$ & 0,400 & 2,390 & 1.67 & 2.39 & Berpengaruh \\
\hline $\mathrm{Px}_{1 \times 3}$ & 0,070 & 0,384 & 1.67 & 2.39 & $\begin{array}{l}\text { Tidak } \\
\text { berpengaruh }\end{array}$ \\
\hline $\mathrm{Px}_{1 \mathrm{y}}$ & 0,224 & 1,260 & 1.67 & 2.39 & $\begin{array}{l}\text { Tidak } \\
\text { berpengaruh }\end{array}$ \\
\hline $\mathrm{Px}_{2} \mathrm{x}_{3}$ & 0,215 & 1,260 & 1.67 & 2.39 & $\begin{array}{l}\text { Tidak } \\
\text { berpengaruh }\end{array}$ \\
\hline $\mathrm{Px}_{3 \mathrm{y}}$ & 0,536 & 3,478 & 1.67 & 2.39 & Berpengaruh \\
\hline
\end{tabular}

Dari hasil perhitungan koefisien Jalur langsung didapatkan pengaruh secara positf motivasi (X2) terhadap jasa pelayanan (X1) sebear 53,5\% , motivasi (X2) terhadap kinerja dokter (Y) sebesar $40 \%$ dan disiplin (X3) terhadap kinerja Dokter (Y) sebesar $53,6 \%$. Sehingga didapatkan gambar jalur patch sebagai berikut

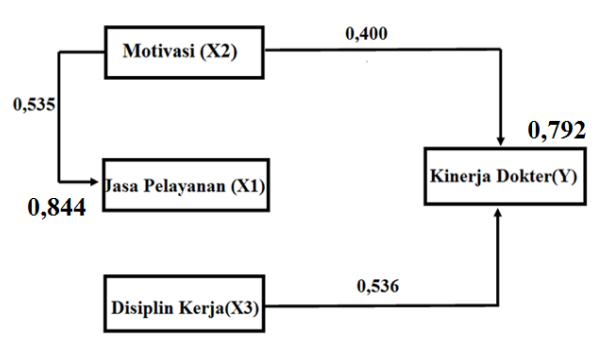

II. Pengaruh Tidak Langsung

1. Jasa Pelayanan (X1), Disiplin Kerja (X3) terhadap Kinerja Dokter (Y)

Nilai untuk pengaruh Jasa pelayanan (X1) terhadap kinerja Dokter (Y) sebesar 0,231>005, atau hitung 1,225 < t table 2,045. Maka tidak ada pengaruh Jasa Pelayanan (X1) terhadap Kinerja Dokter(Y). Nilai untuk pengaruh
Disiplin Kerja (X3) terhadap kinerja Dokter $(\mathrm{Y})$ sebesar $0,002<005$, atau $\mathrm{t}$ hitung $3,413<$ t table 2,045. Maka ada pengaruh Disiplin Kerja (X3) terhadapa Kinerja Dokter (Y)

Nilai signifikan pengarus Jasa Pelayanan (X1) dan Disilin Kerja (X3) secara simultan terhadap Kinerja Dokter (Y) sebesar $0.004<0,05$ dan nilai $\mathrm{F}$ hitung $6,900>\mathrm{F}$ tabel 3,32. Sehingga terdapat pengaruh Jasa Pelayanan (X1) dan Disilin Kerja (X3) secara simultan terhadap Kinerja Dokter (Y)

2. Jasa Pelayanan (X1), Motivasi (X2) terhadap Kinerja Dokter (Y)

Nilai untuk pengaruh Jasa pelayanan (X1) terhadap kinerja Dokter (Y) sebesar 0,943>005, atau $t$ hitung $0,014<$ t table 2,045. Maka tidak ada pengaruh Jasa Pelayanan (X1) terhadap a Kinerja Dokter (Y). Nilai untuk pengaruh Motivsi (X2) terhadap kinerja Dokter $(\mathrm{Y})$ sebesar 0,061>005, atau $\mathrm{t}$ hitung 1,948 < t table 2,045. Sehingga tidak ada pengaruh Motivasi (X2) terhadap Kinerja Dokter (Y).

Nilai signifikan pengarus Jasa Pelayanan (X1) dan Motivasi (X2) secara simultan terhadap Kinerja Dokter (Y) sebesar $0.080<0,05$ dan nilai $\mathrm{F}$ hitung $8.768>\mathrm{F}$ tabel 3,32. Sehingga tidak terdapat pengaruh Jasa Pelayanan (X1) dan Motivasi (X2) 
secara simultan terhadap Kinerja

$\operatorname{Dokter}(\mathrm{Y})$

3. Jasa Pelayanan (X1), Motivasi (X2) dan Disiplin (X3) terhadap Kinerja Dokter (Y)

Nilai untuk pengaruh Jasa pelayanan (X1) terhadap kinerja Dokter (Y) sebesar 0,804 >005, atau t hitung $0,251<\mathrm{t}$ table 2,048. Maka tidak ada pengaruh Jasa Pelayanan (X1) terhadap a Kinerja Dokter (Y). Nilai untuk pengaruh Motivsi (X2) terhadap kinerja Dokter $(\mathrm{Y})$ sebesar 0,141>005, atau $\mathrm{t}$ hitung $1,516<\mathrm{t}$ table 2,048. Maka tidak ada pengaruh Motivasi (X2) terhadap a Kinerja Dokter (Y). Nilai untuk pengaruh Disiplin Kerja (X3) terhadap kinerja Dokter (Y) sebesar 0,004>005, atau $\mathrm{t}$ hitung 3,091 < $\mathrm{t}$ table 2,048. Sehingga ada pengaruh Disiplin (X3) terhadapa Kinerja Dokter $(\mathrm{Y})$.

Nilai signifikan pengarus Jasa Pelayanan (X1), Motivasi (X2) dan Disilin Kerja (X3) secara simultan terhadap Kinerja Dokter (Y) sebesar $0.004<0,05$ dan nilai $\mathrm{F}$ hitung $13.643>$ F tabel 2.92 .Sehingga tidak terdapat pengaruh Jasa Pelayanan (X1), Motivasi (X2) dan Disiplin Kerja secara simultan terhadap Kinerja Dokter (Y)
Rangkuman hasil perhitungan dan pengujian koefisian jalur pengaruh tidak langsung

\begin{tabular}{|l|l|l|l|l|}
\hline Jalur & Koefisien Jalur & F hitung & F tabel & Keterangan \\
\hline Px1x3y & 0,532 & 6,900 & 3,32 & Ada pengaruh \\
\hline Px1x2y & 0,392 & 2,765 & 3,32 & $\begin{array}{l}\text { Tidak ada } \\
\text { pengaruh }\end{array}$ \\
\hline Px1x2x3y & 0,474 & 5,571 & 2,92 & Ada pengaruh \\
\hline
\end{tabular}

Berdasarkan tabel di atas didapatkan nilai $F$ hitung $\operatorname{Px} 1 \times 3 y(6,900)$ dan $F$ hitung Px1x2x3y $(5,571)$ lebih besar dari nilai $F$ tabel Px1x3y $(3,32)$ dan $F$ hitung $\operatorname{Px} 1 \times 2 \times 3 y(2,92)$. Sehinga terdapat pengaruh secara langsung. Sedangkan nilai F hitung Px1x2y $(2,765)$ lebih kecil dibandingkan $F$ tabel $(3,32)$, sehingga tidakadapengaruhsecaratidaklangsung. Berdasarkan hitungan jalur secara langsung dan tidak langsung didapatkan ,kesimpulan bahwa:

1. Pengaruh Jasa Pelayanan terhadap Kinerja Dokter Spesialis didapat melalui Jalur disiplinkerja di rawat jalan RSUD Banten.

2. Pengaruh Jasa Pelayanan terhadap Kinerja Dokter Spesialis didapat melalui motivasi dengan jalur antara disiplin kerja di rawat jalan RSUD Banten, tidak bisa secara langsung motivasi mempengaruhi kenerja.

Sehingga didapatkan gambar jalur path sebagai berikut:

\section{Gambar Jalur Path.}




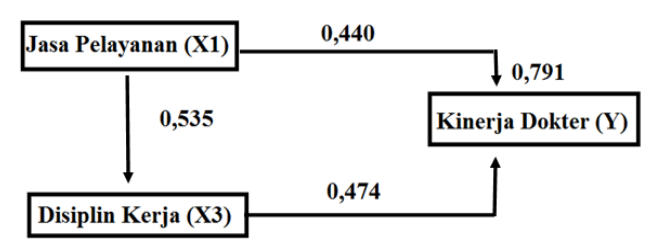

1. Total pengaruh jalur jasa pelayanan (X1) terhadap Kinerja Dokter Spesialis melalui Disiplin Kerja adalah : 0,440+ $(0,535) \times(0,474)=0,440+0,254$ $=0,694$

2. Total Pegaruh jalur Disiplin Kerja terhadap Kinerja Dokter adalah 0,474

\section{Gambaran Deskriptif Responden}

Gambaran Umum responden yang didapatkan pada penelitian ini,rata - rata berumur 35-44 tahun sebanyak 12 orang atau $38 \%$ hal ini disebabkan batas umur dari seorang dokter untuk menjadi Dokter Spesiali smaksimal berumur 35 tahun. Umur Dokter Spesialis yang lebih dari 56 tahun ada satu orang atau $3 \%$, dokter Spesialis tersebut adalah seorang Dokter Spesialis Anestesi Senior. Berdasarkan Jenis kelamin rata-rata dokterspesialis di RSUD Banten adalah Perempuan, sebanyak 19 Orang atau 59\%. Status Perkawinan rata-rata sudah Menikah 97 \%, Responden 100 \% Pendidikan Akademin strata 2 dan Berdasarkan Pendidikan Profesi Sp1 sebanyak 30 orang atau 94\% sedangkan untuk Sp2 hanya 2 orang atau $6 \%$. Distribusi Frekuensi berdasarkan status kepegawaian Dokter Spesialis di RSUD Banten antara ASN dan Non ASN sama banyak sebesar $50 \%$.

\section{Gambaran Karakteristik Jasa Pelayanan Gambaran karakteristik Jasa Pelayanan.} Produksinya bisa berkaitan dan dapat juga tidak berkaitan pada produk yang dapat dilihat. Sedangkan pelayanan kesehatan yang termasuk pada kelompok pelayanan kedokteran dibuktikan dengan cara perorganiasian yang dapat bersifat perorangan atau secara bersama-sma dalam satu organisasi, tujuan pokok untuk menyembuhkan penyakit dan mengembalikan kesehatan, serta sasaran utamanya untuk perorangan dan keluarga. Jasa pelayanan kesehatan semua pengeluaran yang dikeluarkan oleh perusahaan untuk pegawai dan didapatkan serta dinikmati oleh pegawai secara langsung maupun tidak langsung. Variabelvariabel pertanyaan jasa pelayanan pada responeden yakni Dokter Spesialis di Instalasi rawat jalan RSUD Banten yang meliputi gaji yang sesuai dengan pekerjaan Dokter Spesialis, pembayaran gaji tepat waktu, pemberian tunjangan kinerja, pemeberian tunjangan hari raya, pemberian tunjangan profesi Dokter Spesialis dan pemberian asuransi BPJS, dari variabel tersebut semua responden mengatakan rerata dengan pemberian jasa pelayana yang baik, terutama jasa pelayanan yag sangan berpengaruh pada responden adalah kesesuaian gaji dengan 
pekerjaannya sebagai Dokter Spesialis di RSUD Banten dengan persentasi $84,4 \%$

\section{Gambaran KarakteristikMotivasikerja}

Motivasi kerja adalah suatu kondisi dalam dirii ndividu yang mengarahkan, mendorong semangat kerja pegawai demi tercapainya tujuan perusahaan serta kebutuhan individu pegawai.Pekerjaan baru sebagai tantangan. Dari 16 indikator yang digunakan untuk menilai motivasi responden, yaitu dokter spesialis, ada tiga hal yang tidak valid atau tidak sesuai dengan kondisi responden yaitu, kebutuhan akan istirahat tidak terpenuhi, Hubungan yang kurang baik sesama dokterspesialis dan mengeluh dengan beban pekerjaan yang diberikan, hal ini bisa disebabkan oleh karena dokter spesialis masuk enam hari kerja dan menerima konsulan selama 24 jam, sehingga waktu untuk bertemu dengan teman sejawat hanya sebatas ketika ada rapat dengan manajemen. Sedangkan secara rerata responden mengatakan motivasi kerja di RSUD Banten itu baik dengan presentase. Variabel yang sangat berperan dalam memotivasi kerjadokter Spesialis dalam bekerja adalah Pekerjaan baru merupakan tantangan baru yang menyenangkan, karena adanya tantangan akan membuat kemampuan dan ketrampilan semakin berkembang, sehingga lebih siap menghadapi bentuk tantangan yang akan di hadapi. Menurut Siagian, mendefinisikan motivasi kerja sebagai daya dorong bagi seseorang untuk memberikan kontribusi yang sebesar-besarnya demi keberhasilan organisasi mencapai tujuannya, dengan pengertian bahwa tercapainya tujuan organisasi berarti tercapai pula tujuan pribadi para anggota organisasi yang bersangkutan.

\section{Pengertian Disiplin Kerja}

Kesadaran, Kesediaan seseorang mentaati semua peraturan organisasi dan norma sosial yang berlaku. Terdiri dari Disiplin waktu adalah sikap atau tingkah laku meliputi kehadiran, patuh jam kerja dan melaksan akan tugas tepat waktu. Disiplin peraturan adalah tata tertib yang tertulis atau tidak tertulis misalnya seragam. Disiplin Tanggung Jawab adalah penggunan dan pemeliharaan peralatan kedokteran yang digunakan. Dari 8 indikator yang digunakan untuk menjawab masalah disiplin Kerja Dokter Spesialis di RSUD Banten, didapatkan hasil yang tidak sesuai dengan kondisi responden yaitu berupa pemakaian seragam dokter dalam memberikan $p$ Pelayanan kepada pasien di poli atau rawat inap, banyak para responden tidak menggunakan seragam sesuai dengan ketentuan yang telah di putuskan oleh direktur RSUD Banten. Indikator yang paling berpengaruh terhadap disiplin Kerja adalah Hadir Tepat waktu saat bekerja dengan presentase $87,5 \%$. Dengan rerata semua indikator adalah baik.

\section{Gambaran Karakteristik Kinerja Dokter} Spesialis.

Kinerja Dokter Spesialis, merupakan prestasi kerja, yakni perbandingan antara hasil kerja yang dapat dilihat secara nyata dengan standar 
kerja yang telah ditetapkan.). Kinerja Dokter Spesialis di RSUD Banten sesuaidengan Surat Keputusan dari Direktur RSUD No. 821/0117/Kes-RSUB, Kinerja Dari 6 indikator variabel Kinerja dokter spesialis, Indikator tidak membolos dalam bekerja pada dokter spesialis terdapat presentasi sebesar $87,5 \%$, melayani pasien dan mendengarkan keluhan pasein sebesar 65,6\% dan Rapat dengan manajemen $81.2 \%$, melihat hasil ini maka kinerja dokter speialis sudah sesuai dengan SK Direktur RSUD Banten, dimana Absensi menduduki peringat pertama sebesar $40 \%$, Melayani Pasien $40 \%$ serta Rapat dengan Manajemen 20\%,hal ini akan berdampak dalam pemberian Tunjangan Kinerja dan tunjangan Profesi. Penelitian Ratry Rasnoputri dalam hubungan kompensasi terhadap kinerja di PT Jasa Marga, Menunjukkan adanya pengaruh yang sangat kuat dan positif terhadap pengaruh kompensasi terhadap kinerja karyawan.

\section{Secara langsung}

\section{A. Jalur Jasa Pelayanan terhadap} Motivasi.

Dari hasil perhitungan koefisien Jalur ini $\mathrm{X} 1$ ke $\mathrm{X} 2\left(\mathrm{Px}_{2} \mathrm{X}_{1}\right)$ didapatkan Koefisien jalur sebesar 53,5 \% $(0,535)$ Untuk uji hipoteses diperoleh nilai $\mathrm{t}=3,465>\mathrm{t}$ table $=2,042$, dan nilai $p$-value $=0,002$ $<0,05$, ini berarti H01 ditolak, dengan demikian variable Jasa Pelayanan berpengaruh langsung secara positif terhadap variabel Motivasi. Penelitian Windy Ira sari Burhan (2015) Hubungan antara Imbal Jasa dan Motivasi kerja Perawat di Puskesmas Manganitu Kabupaten Sangihe juga mendapatkan hasil ada hubungan antara imbal jasa dan Motivasi kerja. Dengan imbalan jasa yang sesuai sehingga dapat memberikan pelayanan yang lebih berkualitas.

\section{B. Jalur Motivasi terhadap Kinerja Dokter.}

Dari hasil perhitungan koefisien Jalur ini $\mathrm{X} 2$ ke $\mathrm{Y}\left(\mathrm{Px}_{2} \mathrm{y}\right)$ didapatkan Koefisien jalur sebesar $40 \%(0,4)$, Untuk uji hipoteses dari table di atas diperoleh nilai nilai $0,023<0,05$, atau t 2,390 > t 2,042 dan nilai $p$-value $=0,023<0,05$, ini berarti H01 ditolak, dengan demikian variable motivasi (X2) berpengaruh langsung secara positif terhadap variabel Kinerja Dokter (Y). Aspek pekerjaan baru merupakan tantangan baru yang menyenangkan. Penelitian Putri Octaviana Sari (2017) dalam Hubungan antara Motivasi Kerja dengan Kinerja Karyawan, didapatkan hasil Variabel motivasi kerja mempengaruhi variabel kinerja karyawan, dengan dominasi aspek tanggung jawab dalam melakukan pekerjaan.

\section{Jalur Disiplin Kerja terhadap Kinerja Dokter.}

Dari hasil perhitungan koefisien Jalur ini $\mathrm{X} 3$ ke $\mathrm{Y}\left(\mathrm{P}_{3} \mathrm{Y}\right)$ didapatkan Koefisien jalur sebesar 53,6\% (0,535), Untuk uji 
hipoteses dari table di atas diperoleh nilai $\mathrm{t}=3,478>\mathrm{t}$ table $=2,042$, dan nilai $p$-value $=0,002<0,05$, iniberarti $\mathrm{H} 1$ diterima, dengan demikian variable disiplin kerja (X3) berpengaruh langsung secara positif terhadap variabel kinerja Dokter. aspek mentaati jam kerja yang telah ditentuakn oleh Rumah Sakit mendapatkan presentasi sebesar 90,6 \%. Penelitian Devi Ayu Damayanti (2017) dalam penelitian pengaruh disiplin kerja terhadap Kinerja Karyawan pada PT XX, mendapatkan hasil disiplin kerja berpengaruh terhadap Kinerja karyawan dengan menciptakan kondisi kerja yang nyaman dan memperhatikan kinerja karyawan untuk sungguhsunguh mengerjakan setiap tugas.

\section{Secara Tidak langsung}

\section{Jalur Jasa pelayanan terhadap} Kinerja dokter melalui Disiplin Kerja.

Pada Jalur Jasa pelayanan terhadap Kinerja dokter melalui Disiplin, didapatkan nilai signifikan pengarus Jasa Pelayanan (X1) dan Disilin Kerja (X3) secara simultan terhadap Kinerja Dokter (Y) sebesar 0.004<0,05 dan nilai $F$ hitung 6,900 > F tabel 3,32. Sehingga terdapat pengaruh Jasa Pelayanan (X1) dan Disilin Kerja (X3) secara simultan terhadap Kinerja Dokter (Y).
Penelitian Veronica Euphracia M Goda (2018) Pengaruh Disiplin Kerja, Kompensasi dan Motivasi Kerja Terhadap Kinerja Karyawan di PT. Andes Agro Investama (AAI). Hasil penelitian menunjukkan disiplin kerja mempengaruhi kinerja karyawan secara positif. Disiplin Kerja, Kompensasi, Motivasi Kerja bersamasama berpengaruh positif terhadap kinerja karyawan

Sehingga dengan demikian jalur pengaruh yang paling baik antara jasa pelayanan terhadap kinerja dokter spesialis adalah jalur tidak langsung baik melalui disiplin maupun melalalui disiplin kerja. Sehingga dalam peningkatan usaha kinerja dokter spesialis

\section{KESIMPULAN}

Jasa Pelayanan Kesehatan adalah semua pengeluaran yang dikeluarkan oleh Rumah Sakit untuk Dokter dan diterima serta dinikmati oleh dokter secara langsung atau tidak langsung. Variabel Jasa Pelayanan Dokter Spesialis di rawat jalan RSUD Banten,Karakterikteristik yang menonjol adalah Gaji yang sesuai dengan Pekerjaan dokter Spesialis, Pembayaran Gaji yang tepat waktu, Pemberian Tunjangan Kinerja, Pemberian Tunjangan Hari Raya, Pemberian Tunjangan Profesi dokter Spesialis dan PemberianAsuransiBPJS.Pemberian Jasa Pelayananyangdilakukan oleh RSUD Banten sudahBaik,terutama adalah kesesuaian Gaji 
dengan Pekerjaannya sebagai dokters pesialis di RSUD Banten denganpresentasi 84.4\%.

Pada Karakteristik Disiplin Kerja Dokter Spesialisdi RSUD Banten, didapatkan hasil yang tidak sesuai dengan kondisi dokter yaitu berupa pemakaian seragam dokter dalam memberikan pelayanan kepadapasien di polir awat Jalan atau rawat inap, banyak para Dokter tidak menggunakan seragam sesuai dengan ketentuan yang telah di putuskan oleh direktur RSUD Banten. Indikator yang paling berpengaruh terhadap disiplin Kerja adalah Hadir Tepat waktu saat bekerja dengan presentase $87,5 \%$. Dokter variabel Kinerja dokter spesialis, Indikator tidak membolos dalam bekerja pada dokter spesialis terdapat presentasi sebesar $87,5 \%$, melayani pasien dan mendengarkan keluhan pasein sebesar 65,6 \% dan Rapat dengan manajemen $81.2 \%$, melihat hasil ini maka kinerja dokter speialis sudah sesuai dengan SK Direktur RSUD Banten, dimana Absensi menduduki peringat pertama sebesar $40 \%$, Melayani Pasien $40 \%$ serta Rapat dengan Manajemen 20\%, hal ini akan berdampak dalam pemberian Tunjangan Kinerja dan tunjangan Profesi.

\section{SARAN}

Hal pemberian Jasa Pelayanan maka diharaphkan Pihak Manajemen atau Rumah sakit tetap konsisten dalam hal Jasa Ini, baik pemberian Jasa secara Langsung dan tidak langsung berupa Gaji, Tunjangan Kinerja, TunjanganProfesiDokter, Tunjangan Hari raya serta Asuransi BPJS. Ketepatan waktu pembayaran dan Transparan dalam penghitungan pemberian Jasa untuk dokter Spesialis.

Disiplin mengenakan seragam dokter/ snelli dokter dalam hal saat memberikan pelayanan kepada pasien harus tegas dilakukan hal ini berkaitan dengan kedispillin pegawai rumah sakit dalam mengenakan seragam sesuai dengan profesi dan pengenalan seorang dokter oleh pasien. Mengenai ketepatan hadir sudah cukup baik dan perlu ditinagkatkan kembali. Kinerja dokter spesialis di Instalasi rawat jalan RSUD Banten sudah sesuai dengan apa yang dikehendaki oleh manajemen atau Rumah Sakit berupa SK Direktur yang menyangku $t$ Kehadiran, Melayani Pasien di poli rawat jalan maupun poli rawat Inap serta mengikuti rapat dengan manajement harus tetap dipertahankan, agar visi dan misi rumah sakit Umum Daerah Provinsi Banten tetap terjaga dengan baik. 


\section{DAFTAR PUSTAKA}

1. Ardana. 2012. Manajemen Sumber Daya Manusia. Yogyakarta: Grahallmu

2. Arip, Ishak dan Tanjung Hendri. 2003. Manajemen Motivasi. Jakarta: PT. Gramedia Widiarsarana Indonesia

3. Cahyono, Suharjo B. 2008. Membangun Budaya Keselamatan Pasien dalam Praktik Kedokteran. Yogyakarta: Kanisius

4. Devi Ayu Damayanti 2017. Pengaruh Disiplin Kinerja Di Lingkungan Kerja Terhadap Kinerja Karyawan PTP XX. Skripsi. Universitas Lampung.

5. Edi Sutrisno. 2009. Manajemen Sumber Daya Manusia. Jakarta: Kencana

6. Faostino Cardoso Gomes. 2003. Manajemen Sumber Daya Manusia. Yogyakarta: ANDI

7. Fried, B., Fottler, D., 2008. Human Resources in Healthcare: Managing for Success, Third Edition, Health Administator Press, Chicago

8. Gibson, dkk. 1987. Organisasi: Perilaku, Struktur, Proses, EdisiKelima, Jilid I, Alih Bahasa Djarkasih. Jakarta: Erlangga

http://ejournal.urindo.ac.id/index.php/MARSI
9. Heru Yulianto 2015. Persepsi Dan Ekspektasi Dokter Terhadap Jasa Medis Di Rs Pku Muhammadiyah Nanggulan. Yogyakarta: MRS 15 UMY

10. Gondo kusumo, A.A.1998. Komunikasi Pengusaha. Jakarta: PT Gunung Agung.

11. Handoko, T. Hani. 2011. Manajemen Personalia Dan Sumber Daya Manusia. Jakarta: Erlangga

12. Hasibuan, Melayu,S.P. 2009. Manajemen Sumber Daya Manusia. Edisi Revisi. Cetakan Ketujuh. Jakarta: BumiAksara

13. Mangku negara, Anwar Prabu. 2010. Evaluasi Kinerja Sumber Daya Manusia. Bandung: Refika Aditama

14. Mangkunegara, Anwar Prabu. 2014. Evaluasi Kinerja Sumber Daya Manusia. Bandung: Refika Aditama

15. Mangku prawira, Sjafri dan Aida Vitayala Hubies. 2007. Manajemen Mutu Sumber Daya Manusia. Cetakan pertama. Bogor: Ghalia Indonesia

16. Mathis, Robert L. and John H. Jackson. 2002. Manajemen Sumber Daya Manusia. Jakarta: Salemba Empat

17. Putri Octaviana sari 2017. Hubungan Antara Motivasi Kerja Dan Kinerja Karyawan. Skripsi. Universitas Muhammadiyah Surakarta

18. Rafi Jodi Kurnia 2016. PengeruhKompensasi Dan Motivasi Kerja Terhadap Kierja Karyawan Rumah Sakit Condong Catur Yogyakarta. Skripsi. Universitas Negeri Yogyakarta.

19. Ratry Rasno Putri 2012. Hubugan Kompensasi Terhadap Kinerja di PT Jasa Marga. Skripsi. Universitas Indonesia Jakarta

20. Resti Lufita sari.2014. Pengaruh Motivasi Kerja, Disiplin Kerja Dan Kompensasi 
Terhadap Kinerja Karyawan pada Dinas Pendapatan, Pengelolaan Keuangan Dan Aset D.I Yogyakarta. Skirpsi.UNY

21. Rita wati. 2015. Peran Kompensasi Terhadap Peningkatan Kinerja Karyawan Pada Perbankan Syariah Palembang. I-Finance. Vol. 1. No. 1. Juli 2015. 57-72

22. Rivai. 2009. Manajemen Sumber Daya Manusia. Jakarta: Raja Grafindo Persada

23. Rizki Annisa.2019. Analisis Pengaruh Motivasi, Insentife Dan Disiplin Kerja Terhadap Kinerja Pegawai pada Pegawai OPD Kota Bandar Lampung. Skripsi. UNILA

24. Serdamayanti dan Syarifudin Hidayat. 2007. Kinerja Karyawan Dan Metodologi Penelitian. Bandung: Cv. Mandar Jaya

25. Siswanto Sastro hadiwiryo. 2003. Manajemen Tenaga Kerja Indonesia. Jakarta: PT Bumi Aksara

26. Smallwood, P., 2006, Using the JCAHO's Six Competencies to Evaluate MD Performance, _ at http://www.hcpro.com/content.cfm?d $p=$ HOM\&conten_id $=62362 \&$ publicat ion $=3615 \&$ (diunduh 5 April 2020) Sutoto, _, SistemPenilaian Kinerja Individu (Direktur, Dokter, Perawat, Apoteker), Komisi

27. Sofyandi, Herman. 2011. Manajemen Sumber Daya Manusia. Yogyakarta: Grahallmu

28. Sugiyono. 2012. Metode Penelitian Bisnis: Pendekatan Kuantitatif, Kualitatif dan Bisnis. Bandung: Alfabeta

29. Supranto. 2006. Mengukur Tingkat Kepuasan Pelanggan atau Konsumen. Jakarta: Rineka Cipta

30. Surat Keputusan dari Direktur RSUD No.821/0117/Kes-RSUB

31. Sutrisno. 2009. Manajemen Sumber Daya Manusia. Jakarta: Kencana

32. The Joint Commission (TJC), 2011, Standars Booster Pak for Focused Professional Practice Evaluation/Ongoing Professional Practice Evaluation (FPPE/OPPE), Illinois at www. mc.vanderbilt.edu/.../TJC520Booster\% 20Pack\%20FPPE-OPPE.pdf (diunduh 5 April 2020)

33. Triton. 2010. Manajemen Sumber Daya Manusia: Prespektif Partnership Dan Kolektivitas. Jakarta: PT. SukaBuku.

34. Undang-Undang tentang Rumah Sakit Pasal 29b UU No.44/2009.

35. Undang-Undang tentang Rumah Sakit Pasal32 UU No.44/2009.

36. Veronica Eupharicia M Goda. 2018. Disiplin Kerja, Kompensasi Dan MotivasiKerja di PT. Andes Agrolnvestama (AAl). Skripsi. Universitas Sanata Dharma Yogyakarta.

37. Windy Ira Sari Burhan 2015. Hubungan Antara Imbal Jasa dan Motivasi Kerja Perawat di Puskesmas Manganitu Kabupaten Sangibe. Jurnal Keperwatan. Universitas Sam Ratulangi. 